\section{Médecins Sans Frontières (MSF)}

Origin. Médecins Sans Frontières was founded in 1971 by a small group of doctors and journalists who believed that all people have a right to emergency relief.

Functions. MSF was one of the first non-governmental organizations to provide both urgently needed medical assistance and to publicly bear witness to the plight of the people it helps. Today MSF is an international medical humanitarian movement with branch offices in 19 countries. In 2008 MSF volunteer doctors, nurses, other medical professionals, logistical experts, water and sanitation engineers, and administrators departed on more than 4,600 missions and joined more than 23,900 locally hired staff to provide medical aid in over 65 countries. MSF was awarded the 1999 Nobel Peace Prize.

Headquarters: MSF International Office, Rue de Lausanne 78, CP 116, CH-1211 Geneva 21, Switzerland.

Website: http://www.msf.org

Secretary-General: Kris Torgeson (USA).

International Council President: Unni Karunakara (India).

\section{Nobel Prizes}

When the scientist, industrialist and inventor Alfred Nobel died in 1896, he made provision in his will for his fortune to be used for prizes in Physics, Chemistry, Physiology or Medicine, Literature and Peace. The Norwegian Nobel Committee awards the Nobel Peace Prize, and the Nobel Foundation in Stockholm (founded 1900; Mailing address: Box 5232, SE-10245, Stockholm, Sweden) awards the other four prizes plus the Sveriges Riksbank Prize in Economic Sciences in Memory of Alfred Nobel (often referred to as the Nobel Memorial Prize in Economic Sciences). The Prize Awarding Ceremony takes place on 10 Dec., the anniversary of Nobel's death. The last ten recipients of the Nobel Peace Prize, worth $10 \mathrm{~m}$. Sw. kr. in 2011, are:

2002 - Jimmy Carter (USA) for his decades of untiring effort to find peaceful solutions to international conflicts, to advance democracy and human rights, and to promote economic and social development.

2003 - Shirin Ebadi (Iran) for her work fighting for democracy and the rights of women and children.

2004 - Wangari Maathai (Kenya) for her contribution to sustainable development, democracy and peace.

2005 - Mohamed ElBaradei and the IAEA for their efforts to prevent nuclear energy from being used for military purposes and to ensure that nuclear energy for peaceful purposes is used in the safest possible way.

2006 - Muhammad Yunus and Grameen Bank of Bangladesh for their efforts to create economic and social development from below.

2007 - the Intergovernmental Panel on Climate Change and Al Gore for their efforts to build up and disseminate greater knowledge about man-made climate change.

2008 - Martti Ahtisaari (Finland) for his important efforts, on several continents and over more than three decades, to resolve international conflicts.

2009 - Barack Obama (USA) for his extraordinary efforts to strengthen international diplomacy and co-operation between peoples.

2010 - Liu Xiaobo (China) for his long and non-violent struggle for fundamental human rights in China.

2011 - Ellen Johnson Sirleaf (Liberia), Leymah Gbowee (Liberia) and Tawakkul Karman (Yemen) for their non-violent struggle for the safety of women and for women's rights to full participation in peace-building work. Sirleaf is Africa's first and only democratically elected head of state. Gbowee, founder of the Women of Liberia Mass Action for Peace, played a key role as a non-violent force against civil war and Karman is a human rights activist and member of Yemen's leading Islamist opposition party, the Islah. Their work helped strengthen the role of women in endeavouring to bring democracy to nations suffering from autocratic rule and civil strife.

\section{Sveriges Riksbank Prize in Economic Sciences in Memory of Alfred Nobel}

The Sveriges Riksbank Prize in Economic Sciences in Memory of Alfred Nobel was set up by the Swedish central bank in 1968. The last ten recipients of the prize, worth $10 \mathrm{~m}$. Sw. kr. in 2011, are:

2002 - Daniel Kahneman (Israel/USA) for having integrated insights from psychological research into economic science, especially concerning human judgment and decision-making under uncertainty, and Vernon L. Smith (USA) for having established laboratory experiments as a tool in empirical economic analysis, especially in the study of alternative market mechanisms.

2003 - Robert F. Engle III (USA) for methods of analyzing economic time series with time-varying volatility $(\mathrm{ARCH})$, and Clive W. J. Granger (UK) for methods of analyzing economic time series with common trends (cointegration).

2004 - Finn E. Kydland (Norway) and Edward C. Prescott (USA) for their contributions to dynamic macroeconomics: the time consistency of economic policy and the driving forces behind business cycles.

2005 - Robert J. Aumann (Israel/USA) and Thomas C. Schelling (USA) for having enhanced our understanding of conflict and cooperation through game-theory analysis.

2006 - Edmund S. Phelps (USA) for his analysis of intertemporal tradeoffs in macroeconomic policy.

2007 - Leonid Hurwicz (USA), Eric S. Maskin (USA) and Roger B. Myerson (USA) for having laid the foundations of mechanism design theory.

2008 - Paul Krugman (USA) for his analysis of trade patterns and location of economic activity.

2009 - Elinor Ostrom (USA) for her analysis of economic governance, especially the commons, and Oliver E. Williamson (USA) for his analysis of economic governance, especially the boundaries of the firm.

2010 - Peter A. Diamond (USA), Dale T. Mortensen (USA) and Christopher A. Pissarides (Cyprus) for their analysis of markets with search frictions.

2011 - Thomas J. Sargent (USA) and Christopher A. Sims (USA) for their empirical research on cause and effect in macroeconomy. Their independent research focused on how changes in economic policy, such as raising interest rates or cutting taxes, affects different macroeconomic variables, such as GDP, inflation and employment. The work that they did in the 1970s and 1980s has been adopted by policy-makers and researchers worldwide. Their insights are helping to solve the current global economic crisis.

\section{North Atlantic Treaty Organization (NATO)}

Origin. On 4 April 1949 the foreign ministers of Belgium, Canada, Denmark, France, Iceland, Italy, Luxembourg, the Netherlands, 